J. Gen. Appl. Microbiol.

Vol. 1, No. 1, 1955

\title{
THE ELECTRON MICROSCOPIC INVESTIGATION ON CLASSIFICATION OF CONIDIA OF THE GENUS ASPERGILLI*
}

\author{
HIROSHI IIZUKA \\ The Institute of Applied Microbiology, University of Tokyo \\ Received for publication Nov. 8, 1954
}

The nature of the conidial walls and conidiophore walls of Aspergillus oryzae and Aspergillus sojae, (1) which are widely used in Japan for manufacturing alcohol, sake, soy sauce, and soy paste, are the essential characteristics for distinguishing these species from others. Similarly, the nature of conidial walls of Kuro-Koji molds, ${ }^{(2)}$ which are widely used for manufacturing a kind of distilled wine from sweet potatoes in the southern districts of Japan, is one of the essential characteristics for distinguishing it from ordinary Aspergillus niger.

It was proposed by K. Sakaguchi and the present author (1949, 1953, $1954)^{(3)(4)(5)(6)(7)}$ that the electron microscope is an effective and indispensable apparatus for the determination of these characteristics.

As it is well known, the nature of the mature conidial walls of Aspergilli differ from speies to species. This characteristic as well as the size, shape, and color of conidia( ${ }^{(8)(9)(10)(11)}$ are the essential characters used in the taxonomy of this genus. But in some cases, there is no clear dividing line among the different species when observed with an optical microscope and we hesitate over the choice of a suitable descriptive term, or researchers use different terms for the same species.

The author succeeded in showing electron micrographs of conidia of many species of Aspergilli, and to clarify the micro-morphological characters, especially the nature of conidal walls. In order to systematize the descriptive terms for the conidial walls, the author classified the micro-morphological characteristics of the conidia.

\section{MATERIALS AND METHODS}

One hundred forty three typical strains of Aspergilli, obtained from Dept. Agr. Chem. Univ. of Tokyo. Centraalbureau voor Schimmelcultures, and from my own collection, were used in this study.

Conidia obtained from Czapek's solution agar cultures incubated for 21 day at $30^{\circ} \mathrm{C}$ were put on a clean 200 mesh copper screen on which a thin Formvar "(Vinyl acetate formaldehyde polymer)" film ${ }^{(12)}$ or Collodion$\mathrm{SiO}$ film had previously been mounted and dried.

* This was read at the General Meeting to the Agricultural Chemical Society of Japan held in Sapporo, in August, 1953. 
The specimen were examined with a HITACHI type HU-4 or NIHONDENSHI type DA-4, electron microscope.

The electron micrographs were all taken at an electronic magnification of $2500 \times$ or $3000 \times$ and then enlarged.

\section{RESULTS AND DISCUSSION}

1. Contraction of the specimen by the electron beam:

All the specimen were observed under $1 \mathrm{c}<20 \mathrm{~mA}$. Under $1 \mathrm{c}=30 \mathrm{~mA}$, some contraction of the specimen due to the electron beam was observed as shown in Fig. 2, a photograph of Asp. tamarii as an example. The surfaces are covered by conspicuous processes. Fig. 1 was taken at $1 \mathrm{c}<20 \mathrm{~mA}$ and Fig. 2 at $1 \mathrm{c}=30 \mathrm{~mA}$.

2. A "connective" or " disjunctor" a bridge between conidia in the chain:

Fig. 3, a photograph of Asp. usamii, one of the useful black Aspergilli, is an example of conidia during their early stage of growth. They lie down in a thin membraneous tube.

When mature they assume the size and shape characteristic of the species as shown Fig. 4. The "connective" or "disjunctor", the bridge between conidia in the chain, often cited in descriptive literature ${ }^{(10)(13)}$ consists of portions of the outer wall of the thin membraneous tube.

3. Nature of the conidial surface:

Electron micrographs of typical species of Aspergilli are shown in Fig. 5 to Fig. 40 in order to clarify the micro-morphological characters, especially the nature of the surfaces of mature conidial-walls. Many studies have been made of the characteristic size, shape, and surface of mature conidia of Aspergilli from the taxonomical point of view. But in some cases the differences between species are so slight when observed with an optical microscope, that it is difficult to choose a suitable descriptive term and many researchers use the various terms for the same species. In order to systematize the descriptive terms for the conidial walls the author classified the micromorphological characteristics of conidia as shown in Table 1; i.e. the nature of conidial walls are (1) aculeate (Fig. 5 and 6), (2) conspicuously echinulate (Fig. 1, 7, 8, 9, 10, 11 and 28), (3) echinulate (Fig. 12, 13, 14, 15. 16 and 17), (4) delicately echinulate (Fig. 18, 19, 20, 21, 22, 23, 24, 25, 26 and 27), (5) loosely rough (Fig. 4, 29 and 30), (6) spinulose (Fig. 31, 32 and 33) and (7) smooth (Fig. 34, 35, 36, 37, 38, 39 and 40), and the shape of conidia are (I) globose (II) subglobose and (III) elliptical.

4. Differences between optical microscopy and electron microscopy:

a. The conidia of both Asp. candidus Link and Asp. niger mut. c nnamomeus (Schieman) Thom and Raper (=Asp. cinnamomeus Schieman) are globose and have smooth surfaces when observed with an optical microscope. But with the electron microscope, the former is quite smooth (Fig. 34) while the latter is not (Fig. 29).

b. Conidial walls of Asp. melleus Yukawa are recorded as smooth 
Table 1. Classification of the nature of the conidial walls of Aspergilli.

\begin{tabular}{|c|c|c|c|}
\hline $\begin{array}{l}\begin{array}{c}\text { Shape of } \\
\text { conidia }\end{array} \\
\text { Nature of } \\
\text { conidial walls }\end{array}$ & I. globose & II. subglobose & III. elliptical \\
\hline 1. aculeate & A. japonicus Fig. 5. & & $\begin{array}{l}\text { A. aculeatus(7) } \\
\text { Fig. } 6 .\end{array}$ \\
\hline $\begin{array}{l}\text { 2. conspicuously } \\
\text { echinulate }\end{array}$ & $\begin{array}{l}\text { A. carbonarius Fig. } 7 . \\
\text { A. tamarii Fig. } 1 . \\
\text { A. niger Fig. } 8 . \\
\text { A. phoenicis Fig. } 9 . \\
\text { A. pulverulentus } \\
\text { A. parasiticus Fig. } 10 . \\
\text { A. variecolor Fig. } 11 . \\
\text { A. niger mut. schiemanni } \\
\text { Fig. } 28 \text {. }\end{array}$ & & $\cdots \quad \ldots-\cdots$ \\
\hline 3. echinulate & $\begin{array}{l}\text { A. terricola Fig. } 12 . \\
\text { A. fumigatus Fig. } 13 \text {. } \\
\text { A. ustus Fig. } 16 . \\
\text { A. sojae }(3) \text { Fig. } 17 . \\
\text { A. aureus }\end{array}$ & $\begin{array}{l}\text { A. itaconicus } \\
\text { Fig. } 14 .\end{array}$ & $\begin{array}{l}\text { A. ostianus } \\
\text { Fig. } 15 .\end{array}$ \\
\hline $\begin{array}{l}\text { 4. delicately } \\
\text { echinulate }\end{array}$ & $\begin{array}{l}\text { A. ochraceus Fig. } 18 . \\
\text { A. nidulans Fig. } 19 . \\
\text { A. rugulosus Fig. } 20 . \\
\text { A. oryzae Fig. } 21 . \\
\text { A. flavus Fig. } 22 .\end{array}$ & $\begin{array}{l}\text { A. awamori } \\
\text { Fig. } 23 . \\
\text { A. wentii } \\
\text { Fig. } 24 . \\
\text { A. elegans } \\
\text { Fig. } 25 . \\
\text { A. medius } \\
\text { Fig. } 26 . \\
\text { A. restrictus } \\
\text { Fig. } 27 . \\
\text { A. cellulosae }\end{array}$ & A. gracilis \\
\hline 5. loosely rough & $\begin{array}{l}\text { A. usamii. }{ }^{4)} \text { Fig. } 4 . \\
\text { A. inuii( } \\
\text { A. niger mut. cinnamomeus } \\
\text { Fig. } 29 \text {. }\end{array}$ & $\begin{array}{l}\text { A. melleus } \\
\text { Fig. } 30 .\end{array}$ & \\
\hline 6. spinulose & $\begin{array}{l}\text { A. sydowi Fig. } 31 . \\
\text { A. versicolor Fig. } 32 \text {. }\end{array}$ & & $\begin{array}{l}\text { A. repens } \\
\text { Fig. } 33 .\end{array}$ \\
\hline 7. smooth & A. candidus Fig. 34. & $\begin{array}{l}\text { A. sulphureus } \\
\text { Fig. } 35 \text {. } \\
\text { A. flavipes } \\
\text { Fig. } 36 \text {. } \\
\text { A. terrus } \\
\text { Fig. } 37 \text {. }\end{array}$ & $\begin{array}{l}\text { A. clavatus } \\
\text { Fig. } 38 \text {. } \\
\text { A. giganteus } \\
\text { Fig. } 39 \text {. } \\
\text { A. alliaceus } \\
\text { Fig. } 40 .\end{array}$ \\
\hline
\end{tabular}

when observed through an microscope, but with electron microscope they are not (Fig. 30). The projections of conidia are within the limit of the resolution power of optical microscopes.

c. The conidia of both Asp. fumigalus Fresenius and Asp. japonicus Saito are recorded as equally echinulate in many studies. But now it is clear that they are not the same. The author proposes that conidia of Asp. fumigatus is echinulate (Fig. 13) and of Asp. japonicus is aculeate (Fig. 5). 


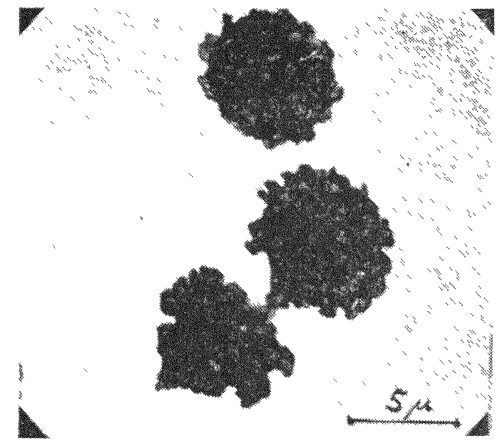

Fig. 1. A. tamarii $\left(\mathrm{I}_{\mathrm{c}}<20_{\mathrm{m}} \mathrm{A}\right)$
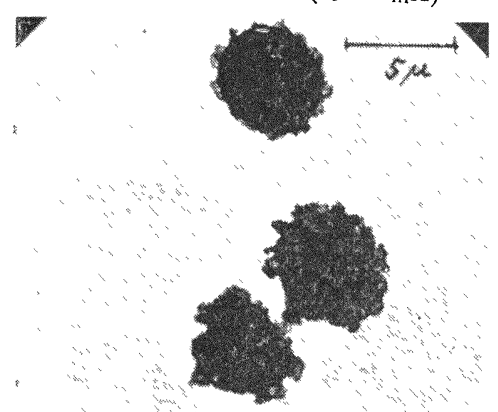

Fig. 2. A. tamarii $\left(\mathrm{I}_{\mathrm{c}}=30_{\mathrm{m} 2} \mathrm{~A}\right)$
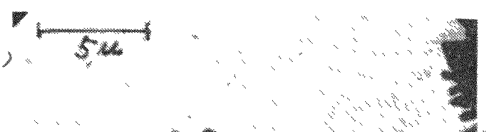

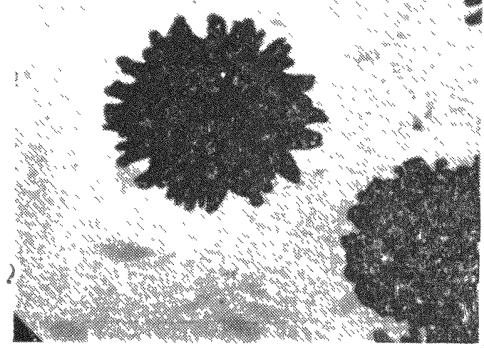

Fig. 7. A. narbonarius

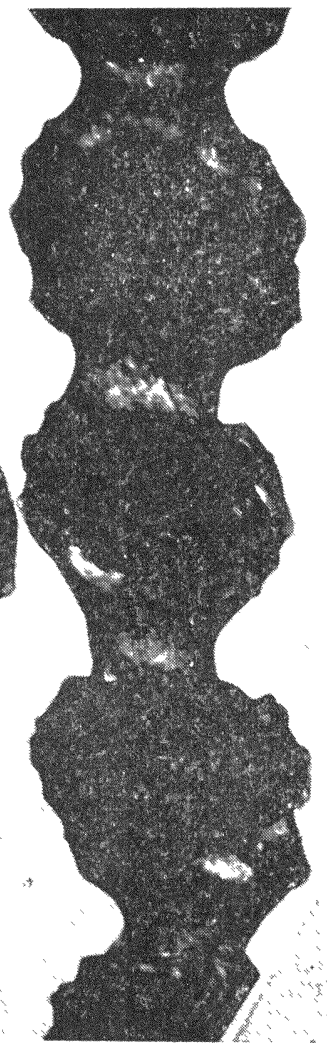

Fig. 3. A. usamii (young stage)

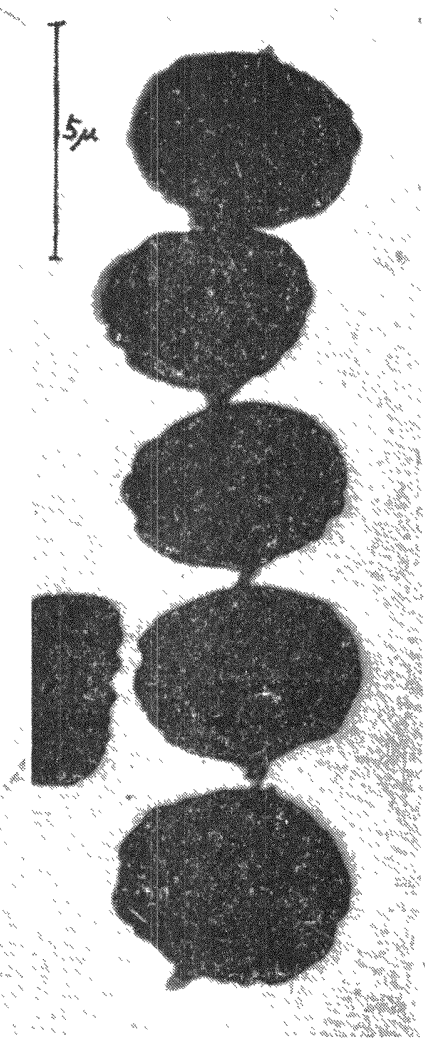

Fig. 4. A. usamii (mature)

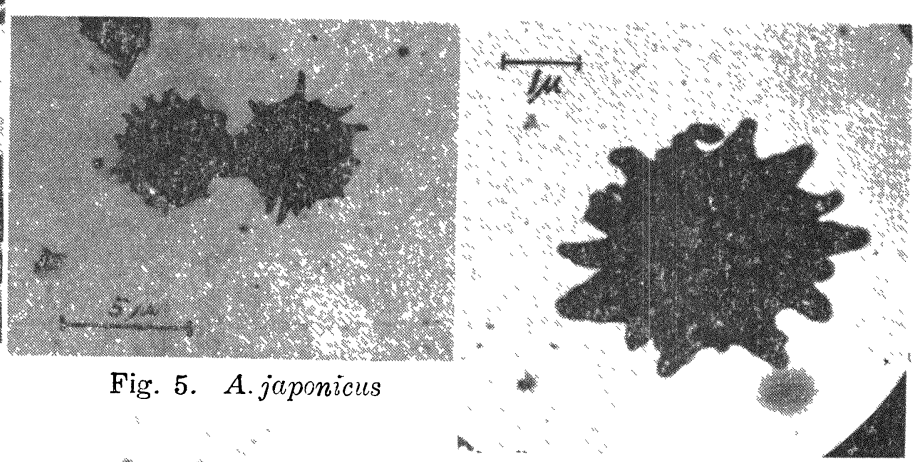

$+7$

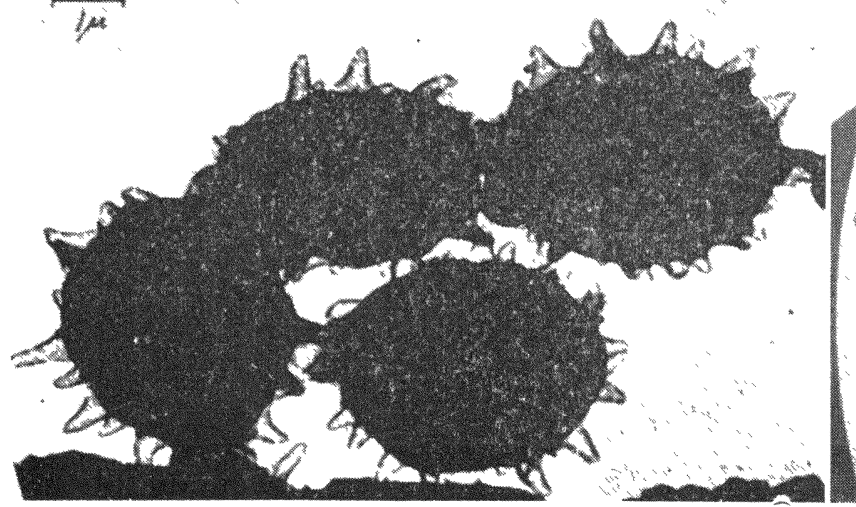

Fig. 6. A. aculeatus

Fig. 8. A. niger

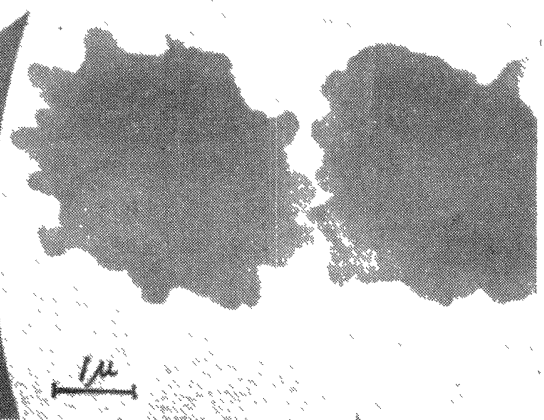

Fig. 9. A. phosnicis 


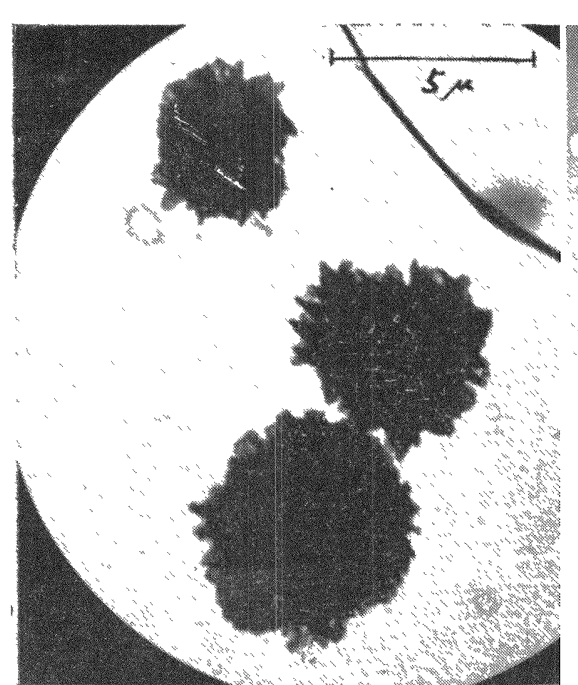

Fig. 10. A.parasiticus
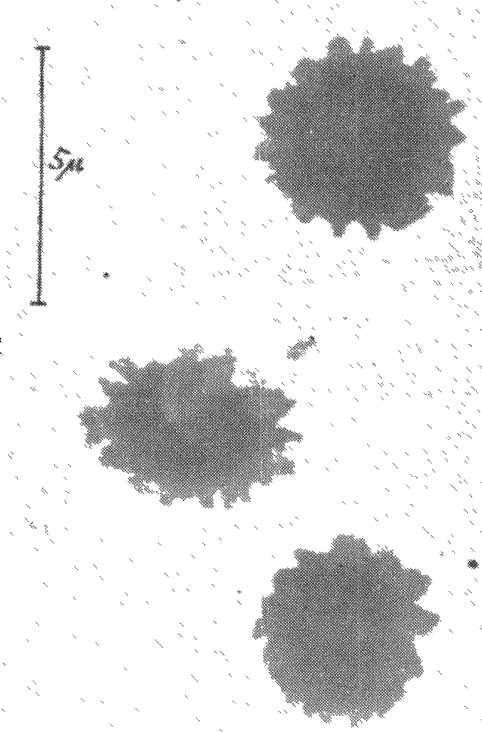

Fig. 11 A.variecolor

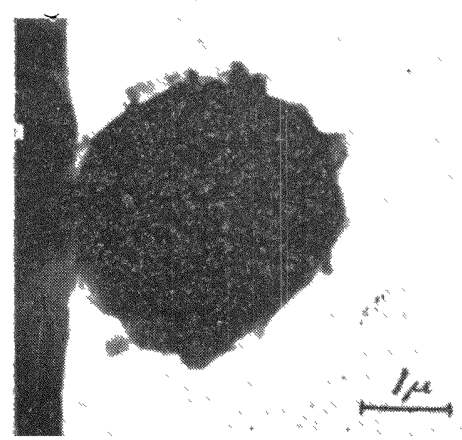

Fig. 15. A. ostianus

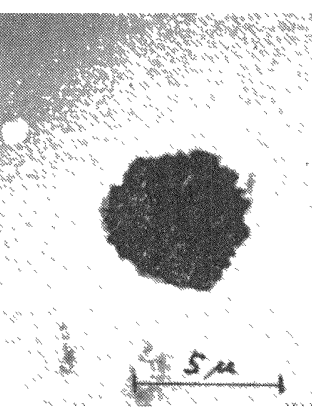

Fig. 12. A.terricola

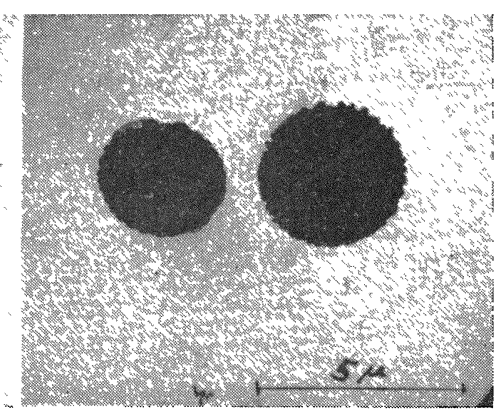

Fig. 13. A. fumigatus I
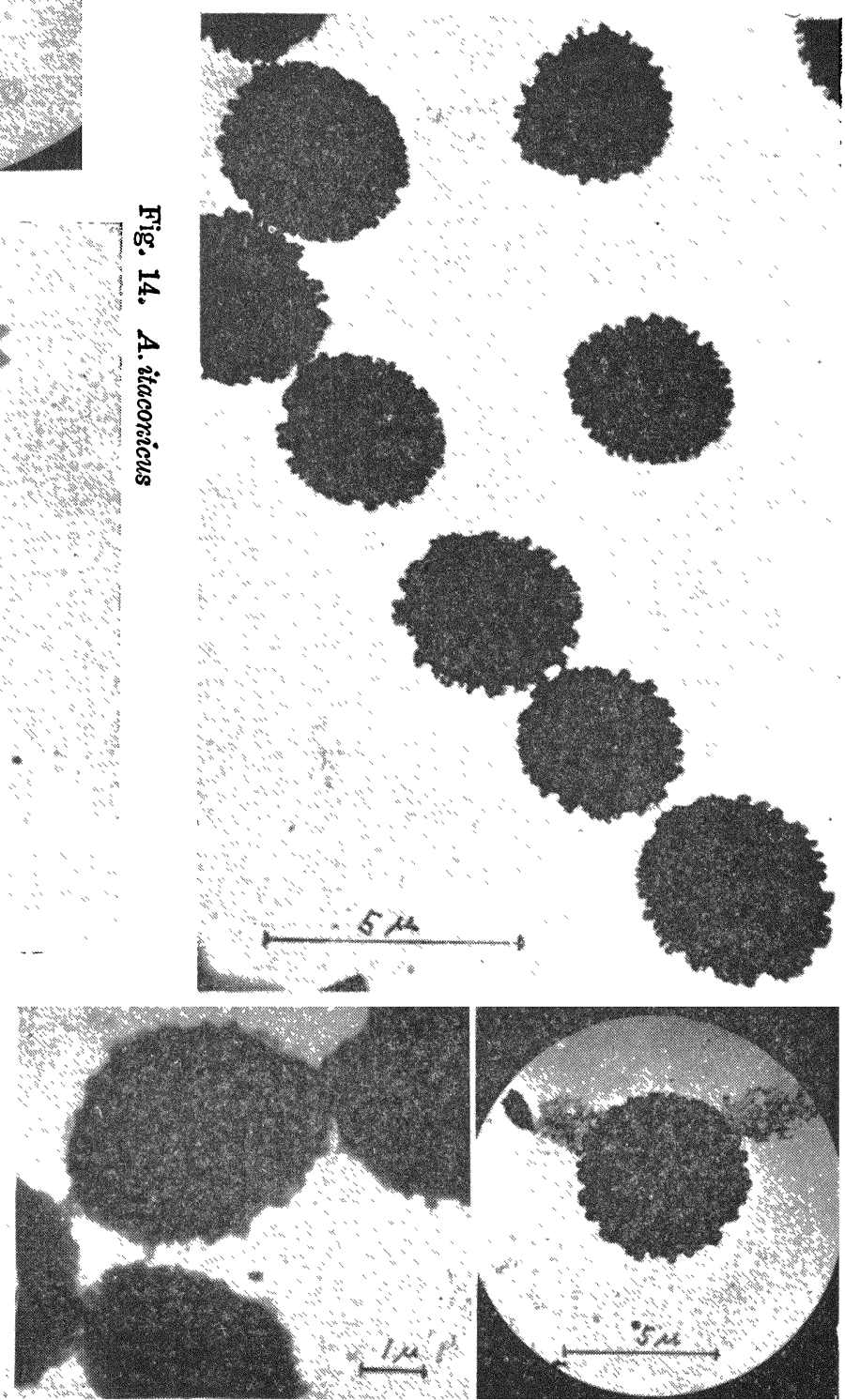

Fig. 16. A.ustus

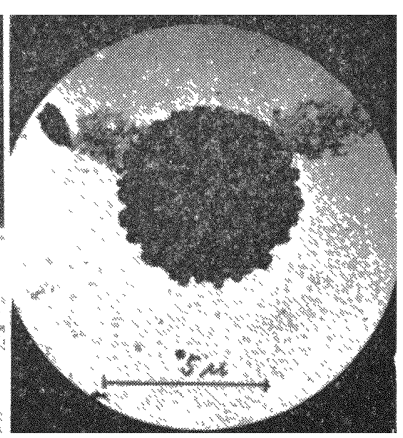

Fig. 17. A. sojae 


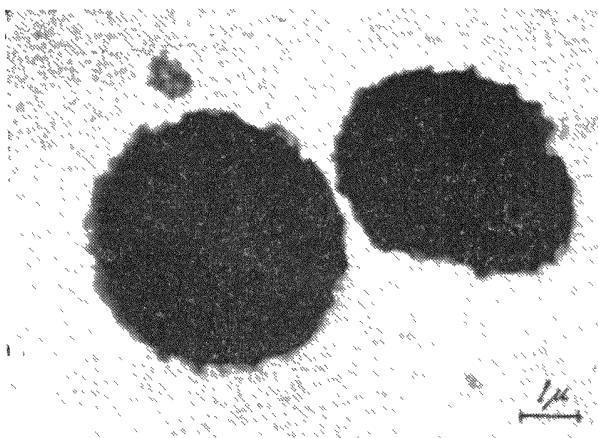

Fig. 18. A. ochraceus

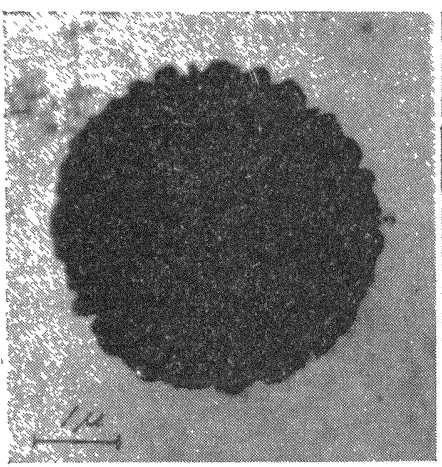

Fig 22. A.flavus

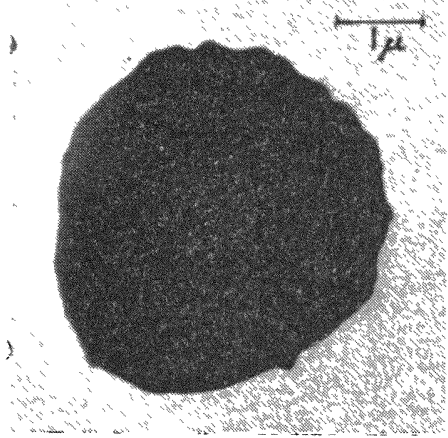

Fig. 23. A. awamori

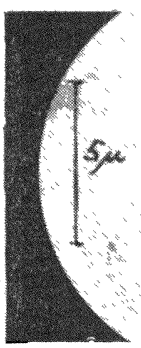

Fig. 19. A. nidulans

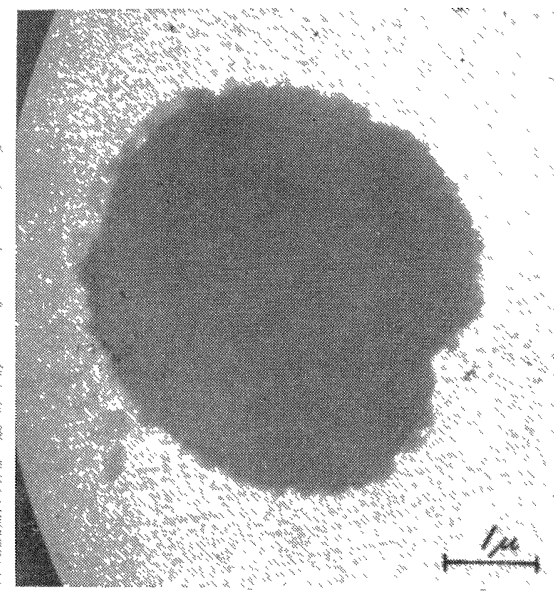

Fig. 24. A.wenti:

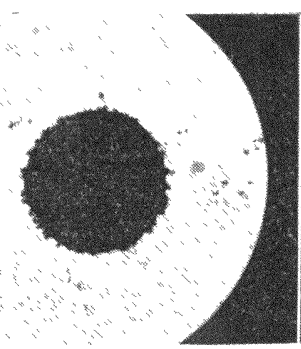

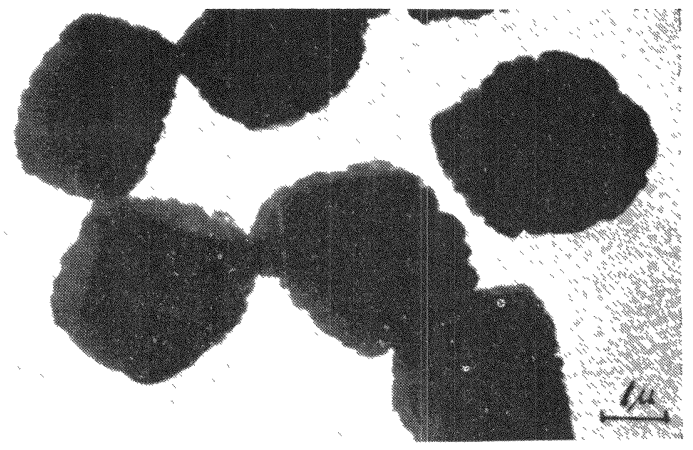

Fig. 20. A. rugulosus

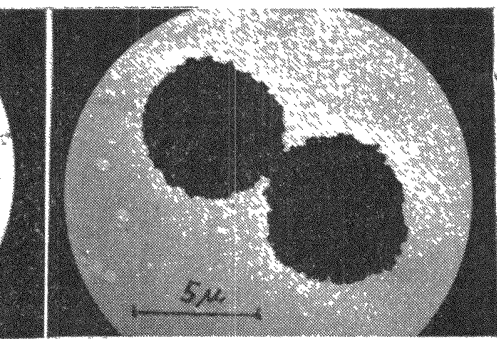

Fig. 21. A.oryzae,
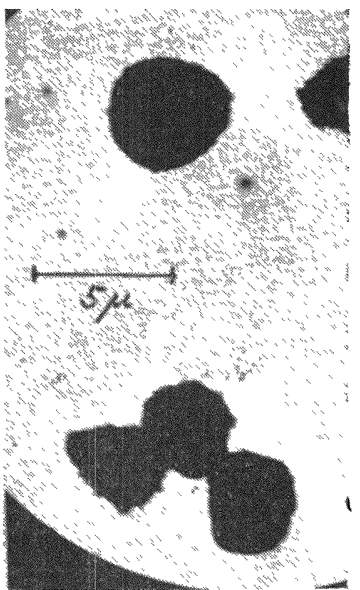

Fig. 25. A. elegans

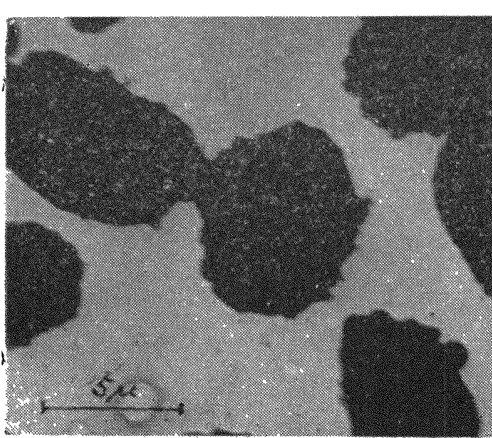

Fig. 26. A, medius

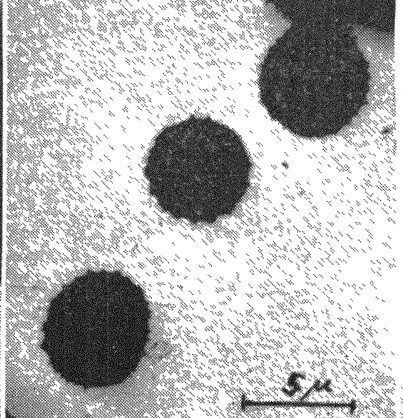

Fig. 27. A. restrictus

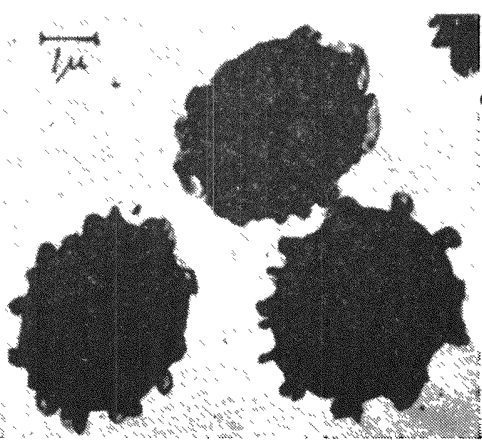

Fig. 28. A. nïger mut. schiemanni 

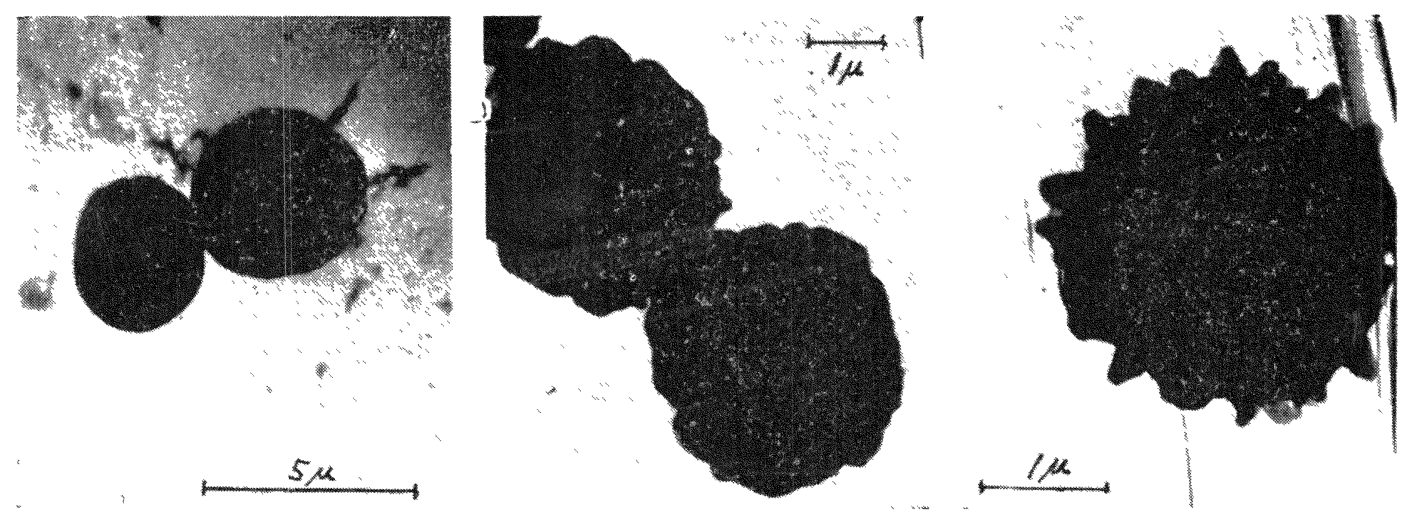

Fig. 29. A. niger mut. cinnamomeus

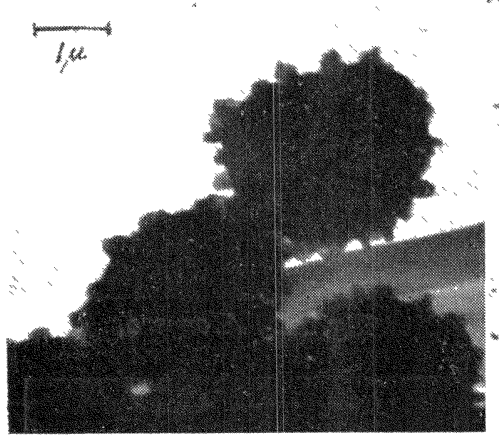

Fig. 32. A. versicolor

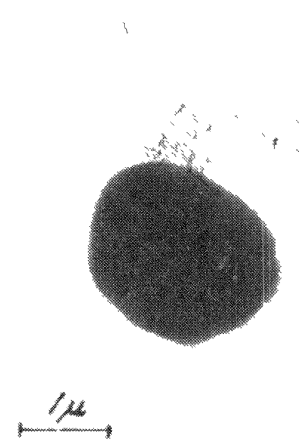

Fig. 35. A. sulphureus

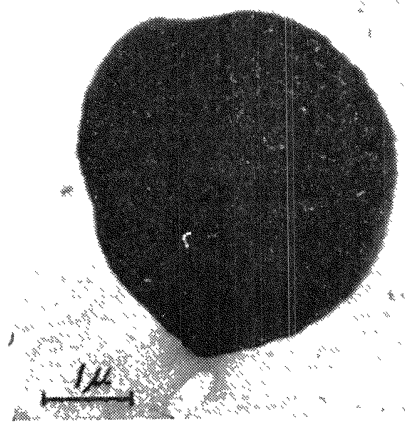

Fig. 38. A. clavatus

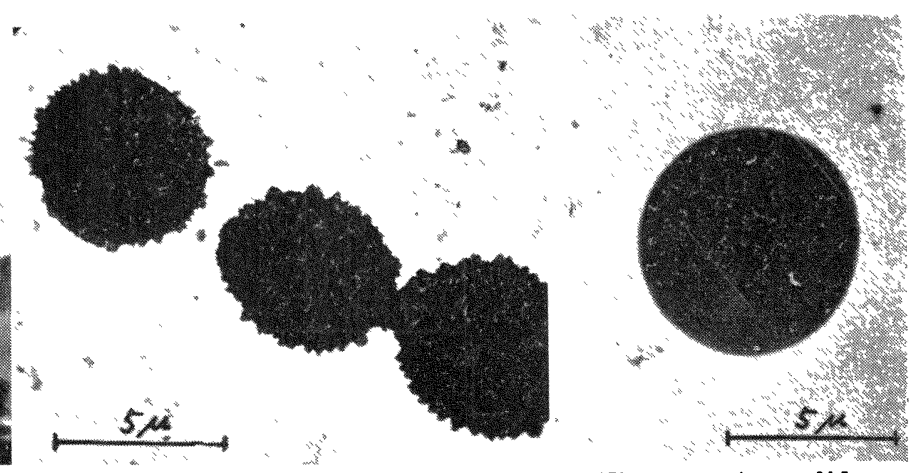

Fig, 33. A. repens

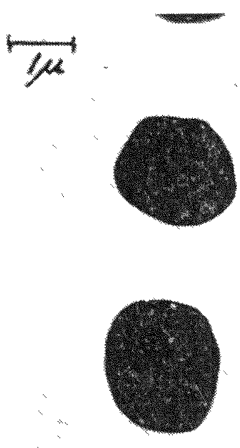

Fig. 36. A. flavipes

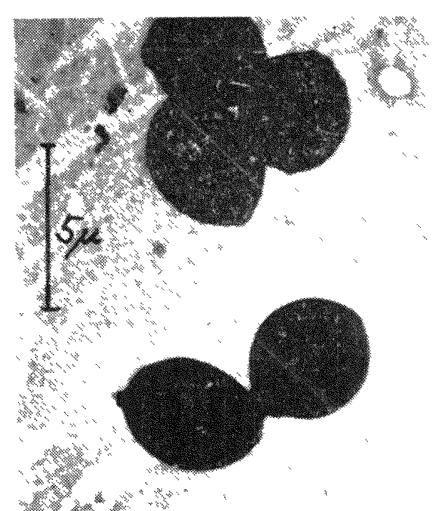

Fig. 39. A. giganteus

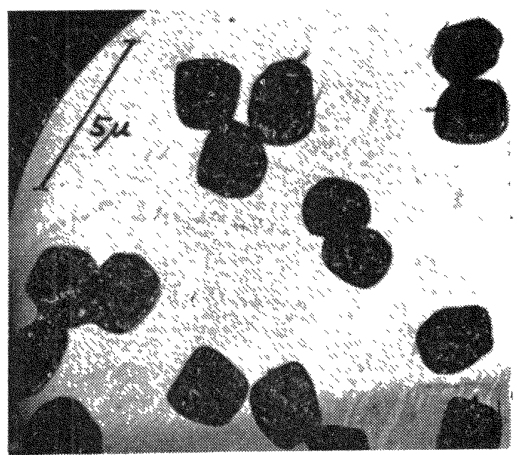

Fig. 37. A. terreus

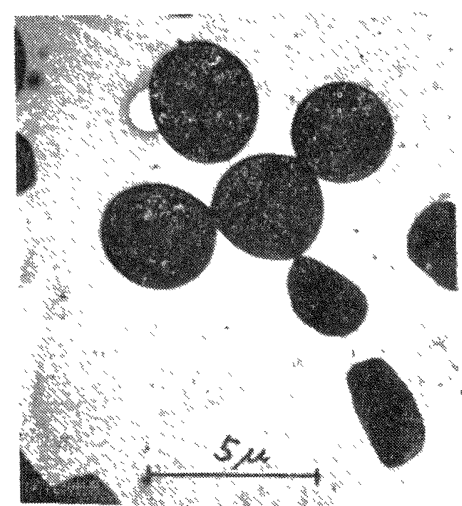

Fig. 40. A. alliaceus 


\section{SUMMARY}

In order to systematize the descriptive terms of the conidial walls, which are one of the essential characteristics in the taxonomy of the Aspergilli, the author classified the micromorphological characteristics of the conidia as observed with an electron microscope.

\section{REFERENCES}

(1) SAKaGUCHI, K. and YAMADA, K.: On the morphology and classification of Koji-molds. Jour. Agr. Chem. Soc. Japan Vol. 20, P. 65 (1944).

(2) Sakaguchi, K., Iizuka, H. and Yamazaki, S.: Jour. Applied Mycology (Univ. of Hokkaido). On the black Aspergilli. Part 1 to 4. Vol. 3, P. 53, P. 65 (1949), Vol. 3, P. 97, Vol. 4, P. 1 (1950) and Jour. Agr. Chem. Soc. Japan Vol. 24, P. 138 (1951).

(3) Sakaguchi, K., Iizuka, H. and Kuroda, T.: On the nature of the conidial walls of Asp. oryzae and Asp. sojae. Jour. Agr. Chem. Soc. Japan Vol. 23, P. 100 (1949).

(4) Sakaguchi, K. and Iizuka, H.: On the nature of the conidiophore-walls of Asp. oryzae and Asp. sojae. ibid. Vol. 27, P. 402 (1953).

(5) SAKaguchi, K. and Iizuka, H.: The taxonomic studies upon the strains NRRL No. 330 and NRRL No. 337. ibid. Vol. 27, P. 524 (1953).

(6) Sakaguchi, K. and Iızuka, H.: Electron microscopic study on the Aspergillus oryzae and Asp. sojae. and Kuro-Koji molds. Electron Microscopy of Japan. Vol. 3, No. 3, P. 174 (1954).

(7) IIzukA, H.: On the morphology and classification of violet-black Aspergilli. Part 1 and 2. Jour. Agr. Chem. Soc. Japan. Vol. 27, 801 (1953), Vol. 27, P. 806 (1953).

(8) Blochwitz, A.: Die Aspergillaceen. Ann. Mycol. 27, S. 229 (1929).

(9) Thom, C. and Church, B. M.: The Aspergilli (1926).

(10) Thom, C. and RAPeR, K. B.: A manual of the Aspergilli (1945).

(11) Wehmer C.: Die Pilzgattung Aspergillus in morphologischer, physiologischer und systematischer Beziehung. (1901).

(12) Wyckoff, R. W. G.: Eiectron Microscopy, chapt. 4 (1949).

(13) Buller, A. H. R. Researches on Fungi V, chapt. 2 (1933). 